\title{
Income status of different fodder farmers in selected areas of Bangladesh
}

\author{
S. Islam ${ }^{1 *}$, J. Begum ${ }^{1}$, N.R. Sarker ${ }^{2}$ and M. Khatun ${ }^{1}$ \\ ${ }^{1}$ Socioeconomic Research Division; ${ }^{2}$ Animal Production Research Division, Bangladesh Livestock \\ Research Institute, Savar, Dhaka.
}

\begin{abstract}
Producing and trading of green fodder are recognised as a profitable venture in many parts of the country, but data and information in this aspect are very scanty. The study determined the income coefficient of fodder farm households to study the fodder marketing and processing in different locations, and highlighted farmers problems related to fodder marketing and processing. In this regard, four study areas were selected from four districts viz: Dinajpur, Jessore, Kurigram and Rangpur purposively considering the concentration of fodder production and marketing. A purposive sampling technique was followed for collecting primary data from the field. In the study 3 categories of sample farmers were selected namely: i) Fodder Producer cum seller; ii) Fodder Producer cum Dairy owner having 1-2 dairy cows as small, 3-4 dairy cows as medium and 5 and above dairy cows as large farmer and iii) Fodder Middlemen. A total of 200 fodder farmers were interviewed. Field survey method and focus group discussions were followed to collect necessary data and information. Descriptive statistics and Cobb Douglas type revenue function were applied to meet the objectives and to get the desirable outputs. Functional analysis revealed that fodder sale and livestock rearing and fodder business significantly contributed to the household income of the fodder farmers and middlemen. The dairy farmers having 1-2, 3-4 and 4-5 cross-bred dairy cattle earned Tk. 1,20,227, Tk. 1,91,728 and Tk. 4,17,287, respectively, whereas local cattle earned Tk. 33, 658, Tk. 51,601 and Tk. 1,13,558, respectively from milk sell annually. It was found that fodder middlemen's income from fodder business highest in Kurigram district and lowest in Jessore district. Fodder processing was not happened in the study areas. Main marketing channels were: (i) Producer cum seller-Dairy owner and (ii) Producer cum seller-Fodder Middlemen-Dairy owner. Fodder farmers faced various socioeconomic problems during its processing and marketing. The major problems were the lack of HYV fodder species, lack of knowledge, lack of input facilities, and lack of marketing facilities. The government should provide HYV fodder, cultivation training, preservation technique, and organized market to the fodder farmers in the study areas.
\end{abstract}

(Key words: Fodder production, fodder marketing, income coefficient)

\section{Introduction}

Livestock sector plays an important role in developing the rural economy of Bangladesh. It provides nutritional foods to million people and serves as the security against crop failure and different natural hazards. Livestock also creates opportunities to exploit common grazing lands, supports collateral and savings, and diversify incomes (Faruque, 2003 ). About $25 \%$ of total population directly depend on livestock rearing and its associated ventures, and $50 \%$ population indirectly related with livestock rearing. The share of livestock sub-sector in the national GDP is $2.45 \%$ (BER, 2013). Therefore, rapid growth of livestock sector is most desirable not only to retain steady agricultural growth but also to lessen rural poverty especially when a majority are small and landless farmers.

Currently, fodder scarcity is becoming a challenging issue in most of the developing

*Corresponding author: s.islam_blri@yahoo.com

Bang. J. Livs. Res. Special Vol. 21-25, 2018: P. 133-141, ISSN 1022-3851 
countries including Bangladesh. Adequate supply of quality fodder and feed is a crucial factor impacting the productivity and performance of the animals. The country is highly deficient in respect of the availability of green fodder, dry fodder and concentrates for various reasons. Low priority efforts to invest in fodder production, lack of post-harvest management for surplus fodder, poor management of pasture lands and inadequate research, extension and manpower support also augmented the deficit situation of fodders. Adequate and steady availability of fodder is a pre-requisite for accelerating the productivity of livestock and to make livestock production cost efficient.

Profitable livestock farming depends mainly on adequate availability of fodder with reasonable price. It comprises a major protein of daily ration of milch animals and therefore cultivation of nutritious and high yielding variety fodder is inevitable. Fodder plays an important role in economising the cost of production of livestock products, especially of milk. Feed and fodder cost constitute about $60-70 \%$ of cost of milk production (Grover et al., 2012). Despite various impediments, livestock farmers are very much eager to produce fodder for their livestock as nutritious feed, source of family income and employment. Many enthusiastic farmers across the country start cultivating fodder for their livestock and for earning income. Although cultivated lands are reducing, but the area and volume of production of fodder is gradually increasing due to the introduction of HYV fodder and better cultural practices (Sayeed et al., 2008). But research work in this aspect is very much limited in Bangladesh. It is expected that the results of the present study would help policy makers, researchers, academicians and development partners in formulating and taking pragmatic decision for further uplifting fodder production in the country. Therefore, the present study was conducted with the following objectives.

a. To determine the income coefficient of fodder farm households;

b. To study the fodder marketing and processing in the areas; and

c. To explore the problems of fodder marketing and processing at farm level.

\section{Materials and Methods}

Multi-strata sampling procedure was followed for collecting primary data for this study. In the first stage of sampling, four fodder growing districts, namely Rangpur, Dinajpur, Kurigram and Jessore were selected purposively. In the second stage, one upazila was purposively selected from each district as the study location considering the concentration of fodder production and marketing. The selected upazilas were Badarganj under Rangpur district, Chirirbandar under Dinajpur district, Kurigram Sadar under Kurigram district and Jessore Sadar under Jessore district. In the third stage, a total of 200 fodder farmers and middlemen taking 50 from each upazila were randomly selected from each selected district. Fodder farmers were grouped into two categories such as: i) Fodder producer cum seller; and ii) Fodder producer cum dairy owner having 1-2 dairy cows as small, 3-4 dairy cows as medium, and 5 and above dairy cows as large farmer. Fodder middlemen were who had taken fodder business as primary occupation. 
Data and information for the present study were collected through administering a pre-tested questionnaire survey among fodder farmers and traders. The survey was confined during December 2013-March 2014 by appointing the field investigators. The field investigators were given training on it so that they would be able to collect quality data from the field. Collected data were coded, tabulated, summarized and processed using computer SPSS Program. The analysis was done using descriptive statistics like percentage, frequency distribution, mean, and rank where appropriate.

\section{Functional analysis}

The following Cobb-Douglas type revenue function model was used to determine the income coefficient of the fodder producer and middlemen.

$\mathrm{Y}=\mathrm{a} \mathrm{X}_{1}{ }^{\mathrm{b} 1} \mathrm{X}_{2}{ }^{\mathrm{b} 2} \mathrm{X}_{3}{ }^{\mathrm{b} 3} \mathrm{X}_{4}{ }^{\mathrm{b} 4} \mathrm{X}_{5}{ }^{\mathrm{b} 5} \mathrm{X}_{6}^{\mathrm{b} 6} \mathrm{e}^{\mathrm{ui}}$

The Cobb-Douglas type revenue function was transformed into following logarithmic form so that it could be estimated by the ordinary least squares (OLS) method. For estimating the income coefficient of fodder producer cum seller, the model was as follows:

In $\mathrm{Y}=\operatorname{Ina}+\mathrm{b} 1 \operatorname{InX} 1+\mathrm{b} 2 \operatorname{In} \mathrm{X} 2+\mathrm{b} 3 \operatorname{In} \mathrm{X} 3+\mathrm{b} 4$ $\mathrm{InX} 4+\mathrm{b} 5 \operatorname{In} \mathrm{X} 5+\mathrm{b} 6 \operatorname{In} \mathrm{X} 6+\mathrm{Ui}$

Where,

$\mathrm{Y}=$ Total household income (Tk./year)

$\mathrm{X}_{1}=$ Income from crop production (Tk./year)

$\mathrm{X}_{2}=$ Income from fisheries (Tk./year)

$\mathrm{X} 3=$ Income from fodder sale (Tk./year)

$\mathrm{X}_{4}=$ Income from service (Tk./year)

$\mathrm{X} 5=$ Income from business (Tk./year)
$\mathrm{X} 6=$ Income from livestock rearing (Tk./year) For estimating the income coefficient of fodder producer cum dairy owner, the model was as follows:

In $\mathrm{Y}=\operatorname{In} \mathrm{a}+\mathrm{b}_{1} \operatorname{In} \mathrm{X} 1+\mathrm{b} 2 \operatorname{In} \mathrm{X}_{2}+\mathrm{b}_{3} \operatorname{In} \mathrm{X}_{3}+$

b4 InX4 + b5InX5+ Ui

Where,

$\mathrm{Y}=$ Total household income (Tk./year)

$\mathrm{X}_{1}=$ Income from crop production (Tk./year)

$\mathrm{X} 2$ = Income from fisheries (Tk./year)

$\mathrm{X} 3$ = Income from service (Tk./year)

$\mathrm{X} 4=$ Income from business (Tk./year)

X5 = Income from livestock rearing (Tk./year)

For estimating the income coefficient of fodder middlemen, the model was as follows:

In $\mathrm{Y}=\operatorname{In} \mathrm{a}+\mathrm{b} 1 \operatorname{In} \mathrm{X}_{1}+\mathrm{b}_{2} \operatorname{In} \mathrm{X}_{2}+\mathrm{b}_{3} \operatorname{In} \mathrm{X}_{3}+$ b4 In X4 + b5 In X5 +Ui.

Where,

$\mathrm{Y}=$ Total Household Income (Tk. /year)

$\mathrm{X} 1=$ Income from crop production (Tk. /year)

$\mathrm{X} 2$ = Income from fisheries (Tk. /year)

$\mathrm{X} 3$ = Income from fodder business (Tk. /year)

$\mathrm{X} 4=$ Income from labour sale (Tk. /year)

$\mathrm{X} 5=$ Income from livestock rearing (Tk./ year)

$\mathrm{a}=$ Constant/intercept;

b1, b2.....b6 $=$ Coefficients of the respective variables; and

$\mathrm{ui}=$ Error term. 


\section{Results and Discussion}

\section{Contribution of different sources to household's gross income}

The household gross income of fodder farmers is likely to be influenced by different sources of income. It was evident that the income from fodder sale significantly contributed to the gross household income of fodder farmers in the study areas. Therefore, an attempt was made to estimate the coefficients of various sources of income to gross income of the fodder farmers.

Table 1 showed that the gross income of fodder producer cum seller consisted of various sources of income in the study areas. Among these sources, fishery, fodder sale, business, and livestock rearing significantly contributed to the gross income of the fodder producers' household. The coefficient of fodder sale income was 0.472 which was significant at $1 \%$ level of confidence with positive sign. This implies that keeping other things constant, $1 \%$ increase in income from fodder sale would lead to an increase in the explanatory variables included in the model explained $93 \%$ of the variation in the total household income of the fodder producer cum seller. Again, the value of ' $F$ ' is highly significant at $1 \%$ level implying that all the included explanatory variables are important for explaining the variations in the gross household income of the fodder producer cum seller.

More or less similar sources of income were found for fodder producer cum dairy owner. Respondent dairy farmers used their entire fodder for dairy production. That's why income from fodder sale was completely absent from the gross household income of the fodder producer cum dairy owners. Table 2 revealed that income from fishery, service, business, and livestock rearing significantly contributed to the gross household income of the fodder producer cum dairy owner. The coefficient of fishery income was 0.441 which was significant at $1 \%$ level of confidence with positive sign. This implies that keeping other things constant, $1 \%$ increase in income from fishery would lead

Table 1. Coefficients of different sources of income for fodder producer cum seller

\begin{tabular}{lccccc}
\hline \multicolumn{1}{c|}{ Explanatory variables } & Coefficients & Std. Error & Probability & Sig. Level \\
\hline Constant & $9.774^{* * *}$ & 0.699 & 15.778 & 0.000 \\
Income from crop production $\left(\mathrm{X}_{1}\right)$ & 0.040 & 0.017 & 0.405 & 0.687 \\
Income from fishery $\left(\mathrm{X}_{2}\right)$ & $0.225^{* *}$ & 0.016 & 2.325 & 0.023 \\
Income from fodder sale $\left(\mathrm{X}_{3}\right)$ & $0.472^{* * *}$ & 0.045 & 4.795 & 0.000 \\
Income from service $\left(\mathrm{X}_{4}\right)$ & 0.093 & 0.020 & 0.963 & 0.339 \\
Income from business $\left(\mathrm{X}_{5}\right)$ & $0.390^{* * *}$ & 0.015 & 3.958 & 0.000 \\
Income from livestock rearing $\left(\mathrm{X}_{6}\right)$ & $0.211^{* *}$ & 0.020 & 2.200 & 0.031 \\
$\mathrm{R}^{2}$ & 0.930 & 0.043 & - & - \\
$\mathrm{F}$ value & $7.404^{* * *}$ & - & - & 0.000 \\
\hline
\end{tabular}

Note: $* * *$ and $* *$ represent significant at $1 \%$ and $5 \%$ level of significant respectively.

annual household income by $0.472 \%$. Similarly, $1 \%$ increase in income from business would lead to an increase in the annual household income by $0.39 \%$. The value of $\mathrm{R} 2$ is 0.93 meaning that the to an increase in the annual household income by $0.441 \%$. Similarly, $1 \%$ increase in income from business would lead to an increase in the annual household income by $0.284 \%$. The value of $\mathrm{R} 2$ is 0.97 meaning that 
the explanatory variables included in the model explained $97 \%$ of the variation in the total household income of the fodder producer cum dairy owner. Again, the value of ' $\mathrm{F}$ ' is highly significant at $1 \%$ level implying that all the included explanatory variables are important for explaining the variations in the gross household income of the fodder producer cum dairy owner. the annual household income by $0.770 \%$. Similarly, $1 \%$ increase in income from livestock rearing would lead to an increase in the annual household income by $0.269 \%$. The value of R2 is 0.83 meaning that the explanatory variables included in the model explained $83 \%$ of the variation in the total household income of the fodder middlemen.

Table 2. Estimation of income coefficient for fodder producer cum dairy owner

\begin{tabular}{l|c|c|c|c}
\hline \multicolumn{1}{c|}{ Explanatory variables } & Coefficients & Std. Error & Probability & Sig. Level \\
\hline Constant & $10.899^{* * *}$ & 0.522 & 20.881 & 0.000 \\
Income from crop production $\left(\mathrm{X}_{1}\right)$ & 0.074 & 0.037 & 0.863 & 0.391 \\
Income from fishery $\left(\mathrm{X}_{2}\right)$ & $0.441^{* * *}$ & 0.018 & 4.923 & 0.000 \\
Income from service $\left(\mathrm{X}_{3}\right)$ & $0.187^{* *}$ & 0.022 & 2.329 & 0.023 \\
Income from business $\left(\mathrm{X}_{4}\right)$ & $0.284^{* * *}$ & 0.015 & 3.363 & 0.001 \\
Income from livestock rearing $\left(\mathrm{X}_{5}\right)$ & $0.312^{* * *}$ & 0.027 & 3.814 & 0.000 \\
$\mathrm{R}^{2}$ & 0.970 & 0.012 & - & \\
F value & $18.662^{* * *}$ & - & - & 0.000 \\
\hline
\end{tabular}

Note: $* * *$ and $* *$ represent significant at $1 \%$ and $5 \%$ level of significant respectively.

Fodder middlemen had taken fodder business as their main occupation to bear the family expenses. Table 3 revealed that income from crop production, income from fodder business, and livestock rearing significantly contributed to the gross household income of the fodder middlemen. The coefficient of fodder business income was 0.770 which was significant at $1 \%$ level of confidence with positive sign. This implies that keeping other
Again, the value of ' $F$ ' is highly significant at $1 \%$ level implying that all the included explanatory variables are important for explaining the variations in the gross household income of the fodder middlemen.

\section{Fodder producer cum dairy owners annual income from milk sale}

It was observed that on an average, the dairy owner having 1-2 cross-bred milch cow

Table 3. Estimation of income coefficient for fodder Middleman

\begin{tabular}{lcccc}
\hline \multicolumn{1}{c}{ Explanatory variables } & Coefficients & Std. Error & Probability & Sig. Level \\
\hline Constant & $0.790^{* *}$ & 1.110 & 0.711 & 0.482 \\
Income from crop production $\left(\mathrm{X}_{1}\right)$ & $0.269^{* * *}$ & 0.006 & 3.426 & 0.002 \\
Income from fishery $\left(\mathrm{X}_{2}\right)$ & 0.108 & 0.009 & 1.325 & 0.194 \\
Income from f odder business $\left(\mathrm{X}_{3}\right)$ & $0.770^{* * *}$ & 0.093 & 10.021 & 0.000 \\
Income from labour sale $\left(\mathrm{X}_{4}\right)$ & 0.089 & 0.006 & 1.057 & 0.298 \\
Income from livestock rearing $\left(\mathrm{X}_{5}\right)$ & $0.283^{* * *}$ & 0.009 & 3.390 & 0.002 \\
$\mathrm{R}^{2}$ & 0.830 & 0.144 & - & - \\
$\mathrm{F}$ value & $33.17^{* * *}$ & - & - & .000 \\
\hline
\end{tabular}

Note: ${ }^{* * *}$ Significant at $1 \%$ level, ${ }^{* *}$ Significant at $5 \%$ level, ${ }^{*}$ Significant at $10 \%$ level.

things constant, $1 \%$ increase in income from fodder business would lead to an increase in earned Tk. 1,20,227 whereas from local cattle Tk. 33,658. It was also observed that 
dairy owner having 3-4 cross-bred dairy cattle earned Tk. 1,91,728 whereas from local cattle Tk. 51,601. In the same way, dairy owner having 4-5 cross-bred dairy cattle earned Tk. 4.17,287 whereas from local cattle Tk. 1,13,558 (Table 4). main methods of processing e.g. silage making and hay making. The farms as they usually preserve crop residues like wheat and paddy for their livestock. Fodder markets were unorganized and unregulated in the study areas. As organized markets have not

Table 4. Annual income of fodder producer cum dairy owners from milk sale (In '000 Taka)

\begin{tabular}{ccccccccccc}
\hline \multirow{2}{*}{$\begin{array}{c}\text { Milch cow } \\
\text { (No.) }\end{array}$} & \multicolumn{2}{c}{ Dinajpur } & \multicolumn{2}{c}{ Jessore } & \multicolumn{2}{c}{ Kurigram } & \multicolumn{2}{c}{ Rangpur } & \multicolumn{2}{c}{ All area } \\
\cline { 2 - 11 } & Cross & Local & Cross & Local & Cross & Local & Cross & Local & Cross & Local \\
\hline $1-2$ & 117.30 & 34.23 & 150.72 & 41.51 & 107.46 & 31.24 & 105.60 & 27.64 & 120.22 & 33.65 \\
$3-4$ & 196.20 & 58.62 & 197.50 & 53.20 & 205.20 & 51.34 & 168.01 & 43.23 & 191.72 & 51.60 \\
$5-6$ & 416.70 & 131.50 & 502.00 & 115.23 & 341.55 & 102.50 & 408.90 & 105.00 & 417.28 & 113.55 \\
\hline
\end{tabular}

Note: Author's calculation based on field survey, 2014

\section{Marketing and processing of fodder}

Farmers of study areas are growing fodder mainly for their livestock. Farmers keep aside a small area for fodder production of their farm area. In the study area, surplus green fodder was sold in the market. It was sold mostly within the village or in nearby markets. The fodder was sold either in bundles or weight basis. Farmers sold green fodder to the fodder middlemen or to dairy owners. The middlemen purchased fodder from the farmer's fodder field. Generally fodder buyers are landless, marginal, and small dairy owners.

Farmers didn't practice the fodder processing method in the study areas. Very few farmers were done fodder processing among the two developed for fodder, hence there was no regular marketing channel. The main channels were: (i) Producer cum seller-Dairy owner and (ii) Producer cum seller-Fodder Middlemen-Dairy owner.

\section{Fodder middlemen's income from fodder business}

The study found that fodder middlemen annual income the highest in Kurigram district that was Tk. 2,10,700 and lowest in Rangpur district was Tk. 1,59,640. Fodder middlemen's average income was Tk. $1,80,760$. It was found that fodder middlemen's income from fodder business highest in Kurigram district that was Tk.1,40,400 and lowest in Jessore district was Tk. $1,23,000$. It was also observed that income share of fodder business to annual income was the highest in Rangpur that was 84.94 per cent and lowest in Kurigram that was Tk. 66.64 per cent (Table 5).

Table 5. Annual income of fodder middlemen (In Taka)

\begin{tabular}{|c|c|c|c|c|c|c|}
\hline Particulars & & Dinajpur & Jessore & Kurigram & Rangpur & All area \\
\hline Annual Income & & 176200 & 176500 & 210700 & 159640 & 180760 \\
\hline $\begin{array}{l}\text { Income } \\
\text { Business) }\end{array}$ & (Fod. & 137400 & 123000 & 140400 & 135600 & 134100 \\
\hline Share $(\%)$ & & 77.98 & 69.69 & 66.64 & 84.94 & 74.82 \\
\hline
\end{tabular}

Source: Author's calculation based on field Survey, 2014 . 


\section{Problems faced by fodder farmers in case of fodder marketing}

The sample farmers who produced fodder faced various problems associated with fodder production, processing and marketing. The reported problems were shown in Table 6 th at were linked with three major areas such as production, marketing and social. Descriptions of these problems are given below:
Lack of transportation facilities: After harvesting of fodder farmers need to sell their produce in the market. As green fodders require more place compare to other crops, so transportation or movement is difficult. Due to lack of proper transportation facilities farmers are not able to bring their produce in the market at right time. On an average, 67 per cent producer and 73 per cent producer cum seller mentioned this is a problem.

Table 6 . Different problems encountered by the fodder farmers

\begin{tabular}{l|c|c|c}
\hline \multirow{2}{*}{ Problems } & \multicolumn{3}{|c}{ Percent of responses (\%) } \\
\cline { 2 - 4 } & $\begin{array}{c}\text { Producer cum dairy } \\
\text { owner }(\mathrm{n}=80)\end{array}$ & $\begin{array}{c}\text { Producer cum } \\
\text { seller }(\mathrm{n}=80)\end{array}$ & $\begin{array}{c}\text { All farmers } \\
(\mathrm{n}=160)\end{array}$ \\
\hline 1. Scarcity and higher wage of labour & 66 & 74 & 70 \\
2. Lack of transportation facilities & 67 & 73 & 70 \\
3. Unorganized and unregulated market & 59 & 73 & 66 \\
4. Lack of marketing facilities & 54 & 66 & 60 \\
\hline
\end{tabular}

Source: Field Survey, 2014.

Farmers in study areas, fodder production for the purpose of sale are a new dimension of farming system. As it is a new marketable agri-product, hence markets were not developed or regulated on that ground. But in the study areas, a good number of fodder middlemen were found who had taken fodder business as a profession. On the ground of fodder marketing, there are some problems that are stated below:

Scarcity of labour and its higher wages: As fodder is labour intensive, so want of labour and its high wages is a major problem. Farmers required machine instead of human labour. About 66 per cent producer and 74 per cent producer cum seller mentioned it as problem.
Unorganized and unregulated market: Farmers in study areas are cultivating fodders mainly for their dairy animals. Many farmers also produce surplus fodder which is generally marketed in the nearby markets or within the village. On the other side, a good number of traders have taken fodder business as a profession. In such a way, fodder production and marketing has added a new dimension in the agribusiness sector in many parts of the country. Being a new product, fodder market is not well developed or regulated. About $66 \%$ fodder producer reported it as a problem.

Lack of marketing facilities: As fodder market is unorganized and unregulated, both fodder farmer and trader can avail of little

Table 7. Probable remedial measures to counter the problems

\begin{tabular}{ccc}
\hline Remedial measures & Producer $(\%)$ & Producer cum seller $(\%)$ \\
\hline 1. Create organized marketing structure & 56 & 62 \\
\hline
\end{tabular}

Source: Field Survey, 2014. 
marketing facilities. About $60 \%$ fodder producers in the study areas uttered the lack of marketing facilities as a problem.

\section{Remedial measures to escalate the fodder marketing}

As farmers faced numbers of problems in case of fodder production, processing and marketing, they also have some suggestions to overcome the marketing impediments. The valued suggestions are listed beneath:

\section{Create organized marketing structure:} Marketing structure is not developed for fodder sale in the study areas. As many people have taken fodder business as their main profession or means of livelihood. Concerned authorities should take necessary attention on this ground. Besides, fodder is directly related with livestock production and its nutrition. On an average, 56 per cent producer and 62 per cent producer cum seller shared their thought in this point.

\section{Conclusion}

The study determined coefficients of different sources of household income, and highlighted the problems faced by the farmers during marketing of fodder. It is revealed that fodder sale and livestock rearing and fodder business significantly contributed to the household income of the fodder farmers. Despite its significant contribution to their gross family income, fodder farmers encountered different socioeconomic problems during its marketing. The problems are unorganized and unregulated market, lack of knowledge, higher wage of labour, lack of transportation and marketing facilities. There is a vast gap between the requirement and availability of fodder in Bangladesh. In order to increase the fodder production and marketing throughout the country, the following steps may be taken into consideration by the government.

- Quality fodder species are not available. Government along with other nongovernment institutions should come forward and take necessary initiatives to promote HYV fodder seed production.

- Government should provide hand-on training on fodder cultivation and its improved preservation technique.

- Organized and regulated marketing structure for surplus fodder is important for increasing fodder production throughout the country. So, concerned authorities should take necessary steps regarding this issue.

\section{Acknowledgement}

The authors are deeply indebted to Dr. Md. Nazrul Islam, Director General of BLRI, for his kind co-operation. The authors are also grateful to Dr. Nathu Ram Sarker, Project Director, Fodder Research and Development Project. The authors express their sincere gratitude to Dr. Md. Mafijul Isalm, Chief Scientific Officer and Head, Socio-economic Research Division, for his analytical help, constant encouragement and valuable suggestions for completing the research timely. The authors are highly grateful to Professor Dr. Taj Uddin, Department of Agricultural Economics, Bangladesh Agricultural University, Mymensingh and Dr. M. A. Monayem Miah, Senior Scientific Officer, Bangladesh Agricultural Research Institute, Gazipur, for their affectionate encouragement and valuable co-operation during the period of study. 


\section{References}

BER, 2013. Bangladesh Economic Review, Ministry of Finance, Government of the Peoples' Republic of Bangladesh, Dhaka.

Faruque, M.G. 2003. Adoption Improved Livestock Production in Practices by Farmers. Progressive Agriculture, Vol. 14 (1\&2): 151-155.

Grover, D. K. and Kumar, S. 2012. Economics of production, processing and marketing of fodder crops in India. http://www. aercpau.com/docs/FODDER_INDIA41
Sayeed, M.A.; Ataur Rahman; A.S.M. Alam, J. Sarker, N.R. and Begum, J. 2008. An Economic study on cultivation of fodder and competing crops in some selected areas of Bangladesh.Annual Report of Annual Research Review Workshop 2008, P 78-79, Bangladesh Livestock Research Institute, Savar, Dhaka. 